\title{
Organisational E-Readiness in the Built Environment: People, Process, Technology
}

Link to publication record in Manchester Research Explorer

\section{Citation for published version (APA):}

Lou, E., \& Goulding, JS. (2009). Organisational E-Readiness in the Built Environment: People, Process,

Technology. In 5th International Structural Engineering and Construction Conference (ISEC-5) (pp. 965-968)

\section{Published in:}

5th International Structural Engineering and Construction Conference (ISEC-5)

\section{Citing this paper}

Please note that where the full-text provided on Manchester Research Explorer is the Author Accepted Manuscript or Proof version this may differ from the final Published version. If citing, it is advised that you check and use the publisher's definitive version.

\section{General rights}

Copyright and moral rights for the publications made accessible in the Research Explorer are retained by the authors and/or other copyright owners and it is a condition of accessing publications that users recognise and abide by the legal requirements associated with these rights.

\section{Takedown policy}

If you believe that this document breaches copyright please refer to the University of Manchester's Takedown Procedures [http://man.ac.uk/04Y6Bo] or contact uml.scholarlycommunications@manchester.ac.uk providing relevant details, so we can investigate your claim.

\section{OPEN ACCESS}




\title{
Organisational E-Readiness in the Built Environment: People, Process, Technology
}

\author{
E.C.W. Lou \& J.S. Goulding \\ Research Institute for the Built and Human Environment (BuHu), \\ University of Salford, Greater Manchester, United Kingdom.
}

\begin{abstract}
Electronic readiness (e-readiness) has predominately been a national issue; however, this is not the case anymore. With today's economic uncertainties and technological advancements, 'organisational ereadiness' is needed for businesses to expand and compete in the global open market. E-readiness for the organisation presents a measure of the degree to which an organisation may be ready, prepared or willing to obtain benefits which arise from the digital economy. To achieve this, organisations need to harness the 'power' of IT by aligning business strategies with e-readiness strategies. For an organisation to be e-ready, a total of 24 factors have been identified across three major issues: People, Process and Technology (and the synergy between them). In this respect, the e-readiness initiative of the organisation must be people and process led, using technology as an enabler. This paper investigates the initiation, development and practice of e-readiness of nations, and presents a case for possible adoption for organisations in the built environment arena.
\end{abstract}

\section{E-READINESS}

The concept of electronic readiness (e-readiness) means different things to different people, in different contexts, and for different purposes. As a result, a large gap exists between ideas and concepts on one hand, and practical applications and implications, on the other (bridges.org, 2005; UN, 2008). Gaps also exist between new expectations and capabilities in place. In discussing the diversity of e-readiness definitions, it is observed that the term "e-readiness" represents the multiple levels of information and Communication Technology (ICT) development, and the exact definition of what constitutes ereadiness is still open for debate. To provide a holistic overview, a few thoughts are outlined to help this discussion. For example, the World Information Technology and Services Alliance (WITSA) states that an e-ready country requires consumer trust in ecommerce security and privacy; better security technology; more trained workers and lower training costs; less restrictive public policy; new business practices adapted to the information age; and lower costs for e-commerce technology (WISTA, 2004). The community assessment of e-readiness by the Center for International Development, Harvard University (2007) describes an e-ready society as one that has the necessary physical: integrated current ICT throughout businesses, communities, and Gov- ernment; strong telecommunications competition; independent regulation with a commitment to universal access; and no limits on trade or foreign investment. Following these themes, e-readiness can also be defined as the aptitude of an economy to use Internet-based computers and information technologies to migrate traditional businesses into the new economy - an economy that is characterised by the ability to perform business transactions in real-time, in any form, anywhere, anytime, and at any price (Bui et al., 2002). Table 1 presents a detailed literature review of the worldwide definitions of ereadiness by leading international groupings, research groups and non-profit organisations.

Table 1: Definitions of e-readiness.

\begin{tabular}{cl}
\hline Report & Definition of e-readiness \\
\hline United Nations & This UN report assesses e- \\
(2008) & government readiness of Member \\
& States, according to a quantitative \\
& composite readiness of e- \\
& readiness based on website as- \\
& sessment; telecommunication in- \\
& frastructure and human resource \\
& endowment.
\end{tabular}


Economist In- E-readiness is the "state of play" telligence Unit of a country's ICT infrastructure (2007) and the ability of its consumers, businesses and governments to use ICT to their benefit. The ranking allows governments to gauge the success of technology initiatives against other countries. It also provides companies that wish to invest in online operations with an overview of the world's most promising investment locations.

Center for In- Readiness is the degree to which ternational Development, Harvard University (2007) a community is prepared to participate in the Networked World. It is gauged by assessing a community's relative advancement in the areas that are most critical for ICT adoption and the most important applications of

The World In- KGT. 'e-ready' country requires formation consumer trust in e-commerce seTechnology curity and privacy; better security and Services technology; more trained workers Alliance and lower training costs; less re(WITSA) strictive public policy; new busi(2004) ness practices adapted to the information age; and lower costs for e-commerce technology.

McConnell In- E-readiness measures the capacity ternational of nations to participate in the (2000) digital economy. E-readiness is the source of national economic growth in the networked century and the prerequisite for successful e-business.

Asian Pacific Readiness is the degree to which Economic Co- an economy or community is preoperation pared to participate in the digital (APEC) (2000) economy. Every economy, regardless of its level of development, presents a readiness profile on the global stage, composed of its national policies, level of technology integration, and regulatory practices.

The various differences in e-readiness definitions raise the question of "what is the most accurate definition for e-readiness"? The answer to this question is an ongoing debate; reflecting that there is no complete literature definition for e-readiness. In spite of all the differences in definitions and opinions, this research takes the position of e-readiness as " $a$ measure of the degree to which a country, nation or economy may be ready, prepared, or willing to obtain benefits which arise from the digital economy".

There are various e-readiness assessments, reports and rankings available to the public, which have been formulated through quantitative and qualitative research by numerous Governments, private and non-profit organisations. Each report is often the product of different methodologies, and divergent definitions of e-readiness. Therefore, the findings of the various studies are predominantly not consistent with each other. Nevertheless, every e-readiness assessment, report and ranking is meant to guide nations by providing benchmarks for comparison and to help gauge progress. However, these can also be useful for judging the impact of ICT, to replace anecdotal evidence and soft non-scientific narrative, with 'concrete' data for example. E-readiness measuring tools from various assessments, reports and rankings can be divided into two main categories: those that focus on the basic infrastructure or on a nation's readiness for business or economic growth (e-economy), and those that focus on the ability of the overall society (e-society) to benefit from ICT (Lou et al., 2008). E-economy tools also include some factors of interest to the larger society, such as privacy and universal access. Broad categorisations for the e-economy include APEC (2000), McConnell (2000) and EIU (2007) reports; and categories for esociety include CID (2007) and UN (2008) reports. For example, the Center for International Development (2007) model investigates how ICT is currently used in society, while the APEC (2000) method focuses on government policies for e-commerce. The e-society tools incorporate business growth and use of ICT as part of their larger analysis, and consider business growth necessary for society's e-readiness. Key indicators from these discussed reports, form the basis of e-readiness for organisations - transforming national perspective into organisation dimensions.

\section{ORGANISATIONAL E-READINESS}

E-readiness within the organisation is built from the rubrics between people, process and technology (Siemieniuch and Sinclair, 2004; CID, 2007; Alshawi, 2007). In this respect, built environment organisations are no different from any other sector specific organisation. These three elements are highly interrelated; for example, developing competence in one element must be accompanied by improvement in the others for the organisation to succeed. Another example is 'process improvement', as 
this is one of the many competence issues that an organisation needs to develop in order to achieve technological capability. By default, this element also requires people with the necessary skills and knowledge to implement process improvements the mandate of which also embodies the creation of an environment that is conducive to, and can facilitate these proposed changes. This organisational context also embraces such levers as motivation, empowerment and the management of change. Thus, it is important to encourage and support the integration between people and process through a flexible and advanced technology infrastructure. Contextually therefore, the key elements of organisational e-readiness should embrace nations' (national) e-readiness reports, rankings, assessments and measuring tools as the building blocks. In this respect, the following subcategories are considered as key enablers of this philosophy. The factors within each element are shown in Table 2.

Table 2: People, process and technology within the e-readiness context

\begin{tabular}{lll}
\hline People & Process & Technology \\
\hline $\begin{array}{l}\text { Leadership \& } \\
\text { Empowerment }\end{array}$ & $\begin{array}{l}\text { Business \& } \\
\text { Information } \\
\text { Process }\end{array}$ & $\begin{array}{l}\text { Connectivity \& } \\
\text { Reach }\end{array}$ \\
\hline $\begin{array}{l}\text { Culture \& So- } \\
\text { ciety }\end{array}$ & $\begin{array}{l}\text { Information } \\
\text { Access \& } \\
\text { Connec- } \\
\text { tivity }\end{array}$ & $\begin{array}{l}\text { IT \& Communica- } \\
\text { tion Infrastructure } \\
\text { (Technology) }\end{array}$ \\
\hline $\begin{array}{l}\text { Human Capital } \\
\text { \& Skills }\end{array}$ & $\begin{array}{l}\text { Security \& } \\
\text { Integrity }\end{array}$ & $\begin{array}{l}\text { IT \& Communica- } \\
\text { tion Infrastructure } \\
\text { (Reliability) }\end{array}$ \\
\hline $\begin{array}{l}\text { Learning \& } \\
\text { Further Educa- } \\
\text { tion }\end{array}$ & $\begin{array}{l}\text { Policy \& } \\
\text { Vision }\end{array}$ & New Technologies \\
\hline $\begin{array}{l}\text { Promotion \& } \\
\text { Facilitation }\end{array}$ & $\begin{array}{l}\text { Knowledge } \\
\text { Sharing \& } \\
\text { Capture }\end{array}$ & New Investments \\
\hline $\begin{array}{l}\text { Change Man- } \\
\text { agement }\end{array}$ & $\begin{array}{l}\text { Services \& } \\
\text { Support }\end{array}$ & $\begin{array}{l}\text { Information Infra- } \\
\text { structure \& Man- } \\
\text { agement }\end{array}$ \\
\hline $\begin{array}{l}\text { Communica- } \\
\text { tion }\end{array}$ & Networked & $\begin{array}{l}\text { Interconnectability } \\
\text { E Interoperability }\end{array}$ \\
\hline $\begin{array}{l}\text { Capacity } \\
\text { Building }\end{array}$ & Web Meas- \\
ure \& Serv- & $\begin{array}{l}\text { Technology } \\
\text { Transfer } \\
\text { ices }\end{array}$ & \\
\hline
\end{tabular}

\subsection{People}

People can be considered as core drivers of a business. As a collective force, they can add value to or- ganisational e-readiness. However, they must be in place to understand organisational processes (implement change where necessary), and use technology to accelerate their efforts. People must however be led - the importance of leadership stems from its role in providing a clear vision of the future, communicating the vision, being able to involve other people in the implementation efforts, being prepared to provide sufficient commitments to the overall efforts and bearing the ability to motivate people rather than directly guiding them (Hammer and Stanton, 1995). However, culture and society within the organisation embodies the organisational behaviour and community, which in turn contributes towards organisational communication (top-down and downup) and change management in the organisation (Diefenbach, 2007). It is therefore essential to obtain optimal human capital and skills, which in turn, is represented through the selecting right people for the right jobs, which could improve innovation and creativity (de Jong and Den Hartog; 2007). The promotion of learning is fundamental to creating a sustainable ICT workforce which supports, underpins, and integrates ICT into the organisation (MacPherson et al., 2005).

\subsection{Process}

Business process is a core indicator of how an organisation functions. As a general rule: the more effective the business processes are, the more efficient the organisation tends to work. Mulcahy (1990) observes, to be successful, a construction organisation must have clear objectives recognising the markets it wishes to address, services it wishes to provide, risk it may undertake, the structure it will use, the environment it will operate within, the controls it will put in place, and the returns it wishes to achieve. Therefore, capturing and disseminating knowledge provides a central organising theme for business change - seen as continuous adaptation and innovation, and concurrently tracking the outside world and internal capabilities, and linking the two together (Nanoka and Takeuchi, 1995). However, processes are not traditionally stand-alone processes, but are often interfaced with people and technology elements. For example, process incentive tasks, such as project collaboration, embodies the people involved in the project, and work processes involved with technology.

\subsection{Technology}

The focus on technology is a major factor behind raising organisational e-readiness; specifically: man- 
aging, operating, standardising, maintaining, forecasting and investing technology is therefore seen as a core function (APEC 2000). The management of ICT is therefore critical in order to ensure that new technologies and emergent economies are successfully leveraged. Therefore, any investment in technology must be aligned with the organisational strategic plan and corporate strategy. In this respect, this alignment can help secure competitive advantage, using ICT a core competency enabler (Alshawi et $a l ., 2008$ ). Thus, the ability of the organisation to securely store and disseminate information; encourage users to contribute and participate in sharing information; and the ability of the organisation re-use information and reward users; represents the highest stage of information infrastructure and management readiness (Boomer, 2006).

This trichotomy of factors (people/process/technology) was also evidenced by Alshawi et al. (2008) through a strategic study into the thinking of UK built environment industry executives and IT/innovation directors, on their perception of investment for ICT-based innovation and competitive advantage. Research findings highlighted a series of 'missed opportunities' between decision-makers. In this context, organisational 'soft' issues tended to be associated with people, process and the work environment. Therefore, organisations need to focus on these areas in order to develop their capabilities in order to be in a state of e-readiness (organisational e-readiness) to effectively absorb technology into their work practices if they are to achieve innovation and competitive advantage.

\section{Conclusion}

E-readiness presents a measure of the degree to which a country, economy or organisation may be ready, prepared or willing to obtain benefits which arise from the digital economy. In this respect, an advanced state of organisational e-readiness is needed for businesses to readily compete in the global open market. However, achieving e-readiness within the context of built environment requires organisations to radically re-think their people/process/technology issues in order to embrace change. For example, organisations in this sector are increasingly dependent on e-commerce, specifically with the increased emergence of electronic transactions and e-tendering. Thus, there is a strong argument that the industry needs to adopt a 'measured approach' in order to help them be 'e-ready'. This ereadiness could be augmented through some form of a practical framework, which would allow them to measure their e-readiness position across the people/process/technology triumvirate.

\section{REFERENCES}

Alshawi, A. (2007), Rethinking IT in Construction and Engineering: Organisational Readiness, Taylor and Francis, UK.

Alshawi, A., Goulding, J.S., Khosrowshahi, F., Lou, E.C.W. and Underwood, J. (2008), Strategic Positioning of IT in Construction. An Industry Leaders' Perspective, Construct I.T. for Business, Manchester, UK.

APEC (2000), E-Commerce readiness assessment guide, Asia-Pacific Economic Cooperation (APEC) Readiness Initiative, Electronic Commerce Steering Group.

Boomer, L.G. (2006), "The 10 rules of technology management", Accounting Today, 20(3), 20-23.

bridges.org (2005), E-readiness assessment: Who is Doing What and Where?, Cape Town, South Africa.

http://www.bridges.org/files/active/0/ereadiness whowhatwhere bridges.pdf [Date accessed 28 February 2008]

Bui, T.X., Sebastian, I.M., Jones,W. and Naklada, S. (2002), E-Commerce Readiness in East Asian APEC Economies - A Precursor to Determine HRD Requirements and Capacity Building, Asia Pacific Economic Cooperation (APEC), Telecommunication and Information Working Group.

CID (2007), Readiness for the Networked World. A Guide for Developing Countries, Information Technologies Group, Center for International Development (CID), Harvard University.

de Jong, J.P.J and Den Hartog, D.N. (2007), "How leaders influence employees' innovative behaviour", European Journal of Innovation Management, 10(1), $41-64$.

Diefenbach, T. (2007), "The managerialistic ideology of organisational change management", Journal of Organizational Change Management, 20(1), $126-144$.

Economist Intelligence Unit (2007), The 2007 ereadiness rankings. Raising the bar, Economist Intelligence Unit (EIU) Research Reports.

Hammer, M. and Stanton, S. (1995), The Reengineering Revolution, Harper Collins, New York, USA.

Lou, E.C.W., Goulding, J. and Alshawi, A. (2008), "Global eReadiness - The alignment of National Policies to Organisational Strategies", $8^{\text {th }} \mathrm{BuHu}$ International Postgraduate Research Conference (IPGRC 2008), Prague, Czech, 135 - 146. 
MacPherson, A., Homan, G. and Wilkinson, K. (2005), "The implementation and use of elearning in the corporate university", Journal of Workplace Learning, 17(1/2), 33 - 48.

McConnell International (2000), Risk E-Business: Seizing the Opportunity of Global E-Readiness, McConnell International and WISTA publishing.

Mulcahy, J.F. (1990), "Management of the Building Firm", Proceedings CIB 90, Joint Symposium on Building Economics and Construction Management, Sydney, Australia, $11-21$.

Nanoka, I. and Takeuchi, H. (1995), The Knowledge Creating Company - How Japanese Companies Create the Dynamics of Innovations, Oxford University Press, Oxford, UK.

Siemieniuch, C.E. and Sinclair M.A. (2004), "A framework for organisational readiness for knowledge management", International Journal of Operations and Production Management, 24(1), 79 -98 .

United Nations (2008), UN E-Government Survey 2008. From E-Government to Connected Governance, Department of Economic and Social Affairs, Division for Public Administration and Development Management, United Nations Online Network in Public Administration and Finance (UNPAN), United Nations Publications, New York, USA.

WISTA (2004), The WITSA Public Policy Report 2004, World Information Technology and Services Alliance (WISTA), Geneva, Switzerland. 